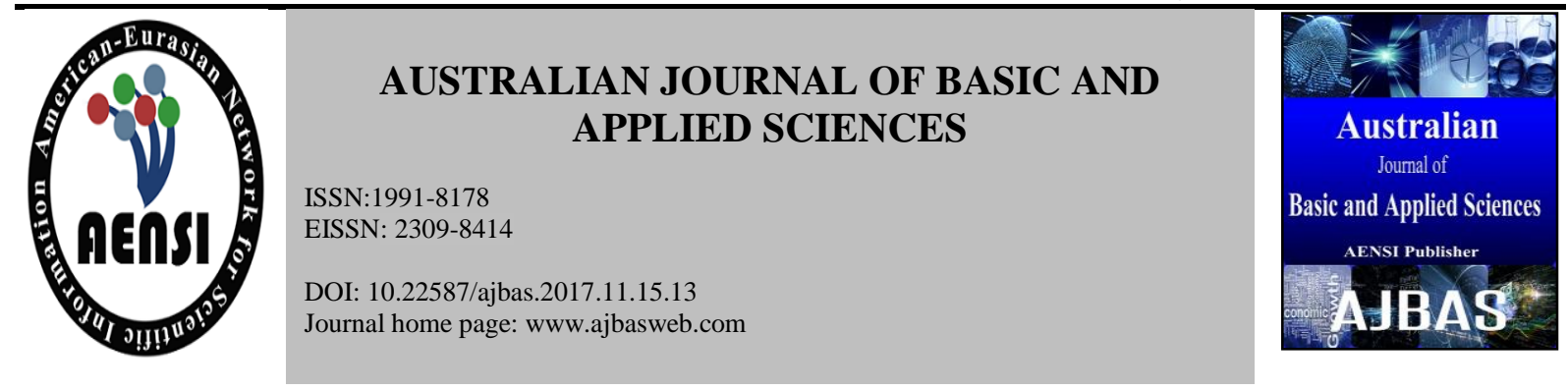

\title{
A Study on the Tactics and Barriers of the Exploitation of Desert- Tourism Resources and Developments in Iran
}

\author{
${ }^{1}$ Annis Nobahar, ${ }^{2}$ Badaruddin Mohamed \\ ${ }^{1}$ Master Student, Universiti Sains Malaysia, Tourism Development School of Housing, Building and Planning, Penang, Malaysia \\ ${ }^{2}$ Dr., Universiti Sains Malaysia, Tourism Development School of Housing, Building and Planning, Penang, Malaysia.
}

\author{
Address For Correspondence: \\ Annis Nobahar, Master Student, Universiti Sains Malaysia, Tourism Development School of Housing, Building and Planning, Penang, \\ Malaysia.
}

Email:anis.pars@gmail.com

\section{ART ICLE INFO}

\section{Article history:}

Received 12 October 2017

Accepted 22 December 2017

Available online 31 December 2017

Keywords:

Desert-Tourism, Iran Tourist, Tourism

Resources Kerman, Shahdad

\begin{abstract}
A B S T R A C T
BACKGROUND: Iran Autonomous Region is one of the most immense region with wide-ranging desert. There has unique and wealthy desert landscape, magical soundsand range. However, the desert development utilization and advertisement lagged behind Kerman province and the great value in the desert itself is not yet incarnated completely. OBJECTIVE: This paper tends to analyzes systematically the characteristics and advantages of desert-tourism in Iran, Kerman. The author proposes some developmental tactics, which are the combination of exploitation and harness and protective development based on the study of orientating. The tourism market of deserttourism, formulating the frame of exploration thinking, which is attaching importance to protection and exploiting skillfully suiting measure to local conditions and striving for benefit enhancing quality and following travelers' needs rather than avoiding duplication and pursuing specialty. RESULTS: Data was collected by distributing 120 questionnaires to the travel agencies as respondent who were specialized in Shahdad Desert. Seven people were selected from authorities of Cultural Heritage, Handicraft \& Tourism Organization in Kerman Province. The data was analyzed the statistical software package SPSS 16.0 for windows and thematic analysis. It is found that some improving of coordination and communication between the private and public sector facility and service providers. The other barriers such as Political and Safety and Human resources are found in this research. CONCLUSION: The desert tourism can be developed and improved through the strategies mentioned in this research. However this cannot be fulfilled unless the authorities of tourism in Iran take this issue into consideration with more responsibility and sympathy.
\end{abstract}

\section{INTRODUCTION}

The depth of travel and tourism in global markets is significant. In the US, for instance, travel and tourism is one of the largest industries, generating US \$2 trillion in economic output. Of the US \$2 trillion, US \$155bn was generated from auto transportation (US Travel, 2013). The phrase 'desert tourism' refers to a diversity of products, experiences and environments. There is no clear single 'desert tourism' market, rather a collection of markets which are characterized by their small scale and complex interactions with natural, social and cultural environments. They can create new jobs, determines the country's economic growth and supports the infrastructure development. The number of travelers in 2010 were around one billion twice as many as it was estimated in 1995. Around $80 \%$ of tourists travelers are from the first twenty richest country (Riasi \& Pourmiri, 2015). Iran also has a lot of tourist attractions, but due to some issues such as the political, economical, cultural, social, and religious issues which have been considered as obstacles to its advancement, this industry have been affected (Kavousy et al., 2009). Travel within the drive tourism sector includes automobiles, motorcycles, four-

Open Access Journal

Published BY AENSI Publication

(C) 2017 AENSI Publisher All rights reserved

This work is licensed under the Creative Commons Attribution International License (CC BY).

http://creativecommons.org/licenses/by/4.0/

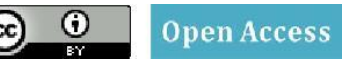

To Cite This Article: Annis Nobahar, Badaruddin Mohamed, A Study on the Tactics and Barriers of the Exploitation of Desert-Tourism Resources and Developments in Iran. Aust. J. Basic \& Appl. Sci., 11(15): 91-97, 2017 
wheel drive vehicles, recreational vehicle travel, and caravanning (Prideaux \& Carson, 2011). The current academic literature has very little to say about 'desert tourism', although cases of tourism in desert areas feature in the discourse on sustainable tourism and eco-tourism more generally. According to The International Ecotourism Society (TIES) 2006, "Nature-based tourism: any form of tourism that relies primarily on the natural environment for its attractions or settings".

On the other hand, One-fifth of the Earth is covered by deserts and the population of the deserts is around 13 percent of the world's population (Quinn, 2008). Regardless of some apparently uneven lands, deserts have large significant matchless natural and human attractions and a great deal of profit can be made thorough industry of tourism if they are supervised correctly. One of the significant parts of the world's natural and cultural heritage is deserts. Deserts are considered as an important support for economic activities. Tourism as one of these economic activities offers employment and job opportunities to local societies (UNEP, 2006).

Along these lines, Iran is a country with very divers' nature, mountains, lakes, caves, forests, deserts, exclusive animal and plant species, various water springs and much more like the several Islands in the south and shores of the Caspian Sea in the north. Hence, the current research is made an attempt to identify the main barriers and strategies to the development of desert tourism in Shahdad Iran. Shahdad is located 100km east of Kerman province. To do so, the quantitative method approach involving a questionnaire survey with closedended questions and qualitative semi-structured interview as a primary data collection method is used to identify the barriers and challenges of desert tourism in Shahdad.

There were some limitations for this study. For example, the authorities of cultural heritage in Kerman city were unavailable most of the time and setting an appointment with them was extremely difficult and it was necessary to call them several times before traveling to Kerman. On occasions interviewees sidetracked the discussion during the interview due to some security issues. Thus it was needed for the interviewer to control and lead the interviewee to the question. In addition we were required to call the agency managers several times before sending them the questionnaire so that they won't forget it. It was also need to refer to them several times to collect a filled questionnaire.

\section{Kerman province and its potential:}

The province of Kerman is a second largest province in Iran covering an area of 181,714 sq. km

located in the south east of Iran.

Fig. 0-1 shows the tourism map of Iran. It takes much of the Dasht-e-Lut desert, and most of the province is largely steppe or sandy desert, though there are some oases where dates, citrus fruits, pistachios and cereals are cultivated. Kerman city and its districts such as Golbaft, Mahan, Shahdad, Rayen are collections of Tourism attractions such as Kerman Bazaar which consists of various rows or alleys like Arg, Ganj Ali Khan, Ekhtiyari, Sardari, Vakil, Attari, Qadam Gah , and Mozaffari rows and some others such as Ganjali Khan Complex, Jabaliye Dome, Yakhchal (ice house) Moayedi, etc.

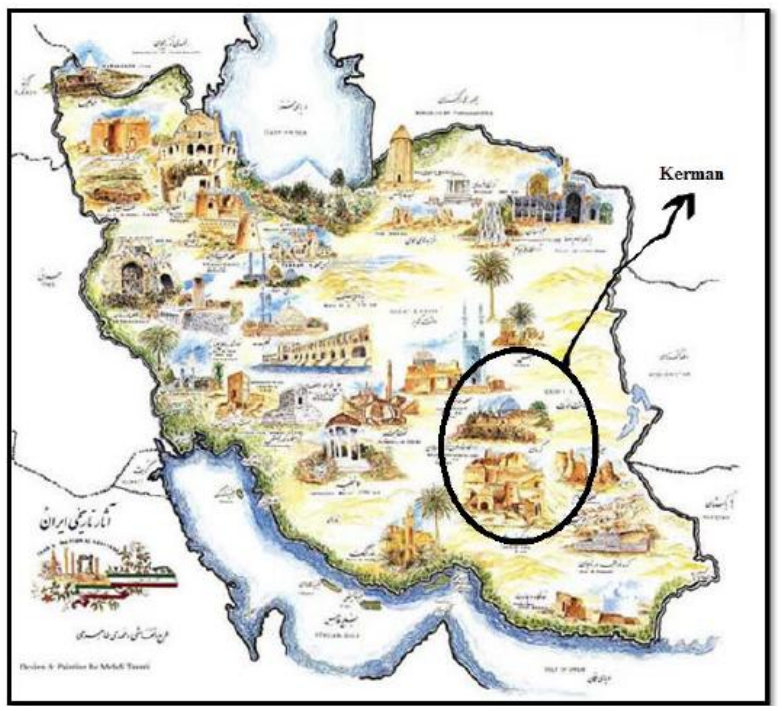

Fig. 0-1: Tourism Map of Iran. 
Shahdad desert is part of Lut Desert. It is an unexplored land which can open a new window to ecotourism in Iran. Desert is not simply a geographical phenomenon, but is also of historical and cultural value. Its starry nights combined with elusive mirages, unparalleled silence, historical monuments and sweet taste of Shahdad dates can appeal to any taste and every nationality. There is also the permanent Shour (salty) river with beautiful salt crystals, Gandom_e Beryan hill, Barout gorge, egg shaped salt formations, as well as desert plants that aggrandize beauty of the desert (see
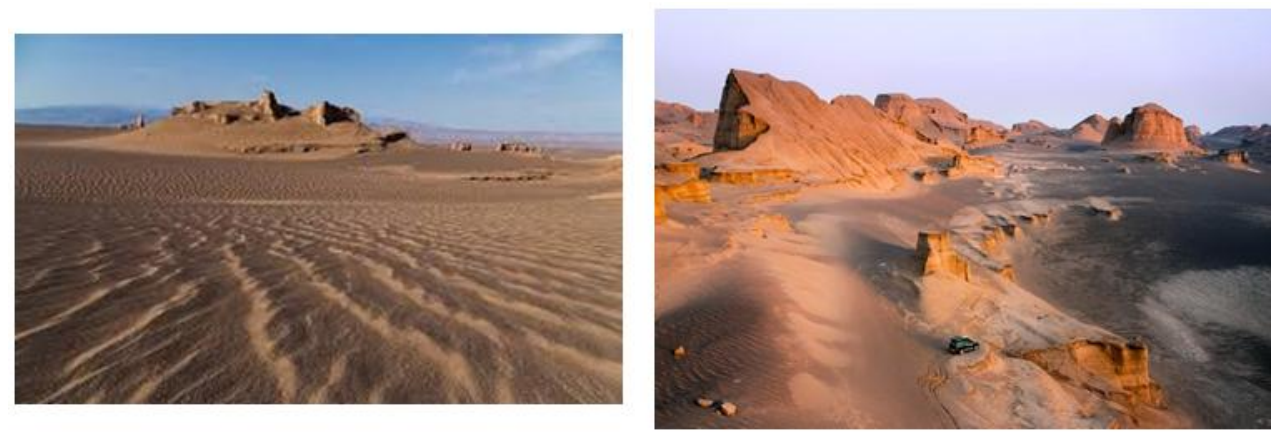

Fig. 0-1).

\section{Planning \& Management of Tourism in Iran:}

Iran covers a land area of 1.64 million $\mathrm{km} 2$. It is classified among the 17 largest countries in the world. The whole area of Iran is divided into four parts: 1/2 mountains, 1/4 deserts and 1/4 fertile plains and other geographical regions. Geographical distribution of income earned by tourism is not equal in the world. Iran has less than $1 \%$ income of Middle East from tourism and the Middle East itself has just 2.5\% income of world's tourism. Unlike many countries, no variation or change in this area of tourism economics will be done in Iran. The number of foreign tourists in Iran has been announced to be 2 million by Cultural Heritage and Tourism Organization (2010), which is regarded as an exaggerated amount by many experts (Keihan newspaper, 2010).
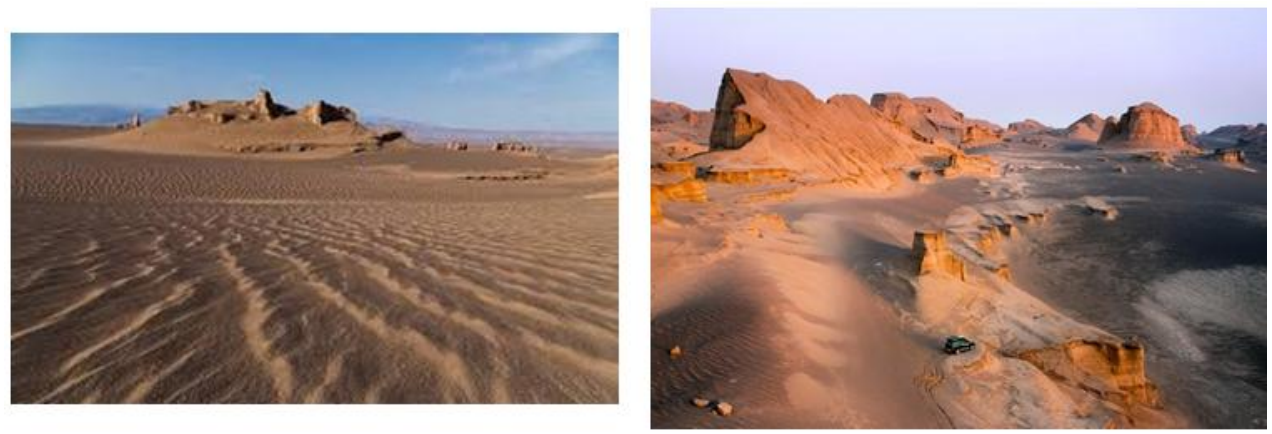

Fig. 0-1: Shahdad Desert.

According to UNESCO, Iran is significant in the world's tourism, due to existence of sea, desert, warm-watered spa, varied wild life, religious tourism attractions, and a seven thousand civilization (Keihan newspaper, 2010). 75\% of the tourists in Iran have been from Azerbaijan, Pakistan, Turkey, and Afghanistan. The tourists of Western Europe were only 5\% and the tourists of continent of America were only 3\%. The tourists from the neighboring countries of Iran that are financially weak have made the income of tourism industry in Iran even less than the average income of South Asia. Hence, it is really necessary to find a solution to attract the tourists of American and European countries so that we can be hopeful about the high incomes. 
Regarding the analysis of available situation and the objectives of Kerman province and countries. Increasing of reformation, renovation, reconstruction of historical structures in the province, keeping the historical, cultural and immaterial values in improvement of local culture, development of tourism industry with proper using of cultural, historical and natural heritage and development of sub-structures of tourism industry for increasing the promotion of tourism sources in the province are the goals of the section of cultural and heritage, tourism and handicraft organization (Iran Touring and Tourism Organization, 2000). The table below shows the number of tourist arrivals to Kerman province has experienced a dramatic decrease in 2010. Although in 2004 to 2009 this number has been increased but due to many problems which have been identified in the result section, the number of arrivals reduced.

Fig. 0-1 displays the number of visitors of Iran (in thousand).

\section{Methodology:}

According to Creswell (1994) a quantitative approach is an inquisition into a social or personal problem, testing theories based on variables, or measuring numbers which are analyzed through statistical procedures in order to prove the preliminary theory to be true. As Creswell (1994) adds a qualitative approach is a paradigm in which a study is defined as an inquiry for understanding a social or personal problem through building a complex picture formed with words which is conducted in natural setting. According to Saunders (2000) there are two types of data, primary and secondary. This study takes the above mentioned approach to analyze the collected data with regard to the Mix method approach. In other words, this study will use the quantitative and qualitative method approach using self-administered written questionnaire and interview (see

Fig. 0-2). The purpose of doing this study questionnaires were used to collect the required data from Tour Agents specialized in desert tourism in two cities of Iran, namely Tehran and Kerman, (Shahdad Desert). A total number of 120 questionnaires were distributed to Tour Agents during 10 days in Kerman and 12 days in Tehran. For the purpose of data collection of qualitative method, seven people namely the Tourism Authority Managers in Kerman were invited for an interview. An official letter on behalf of the school (HBP) was taken to Tourism Organization of Kerman. This letter was also, in the first place, translated into Persian.

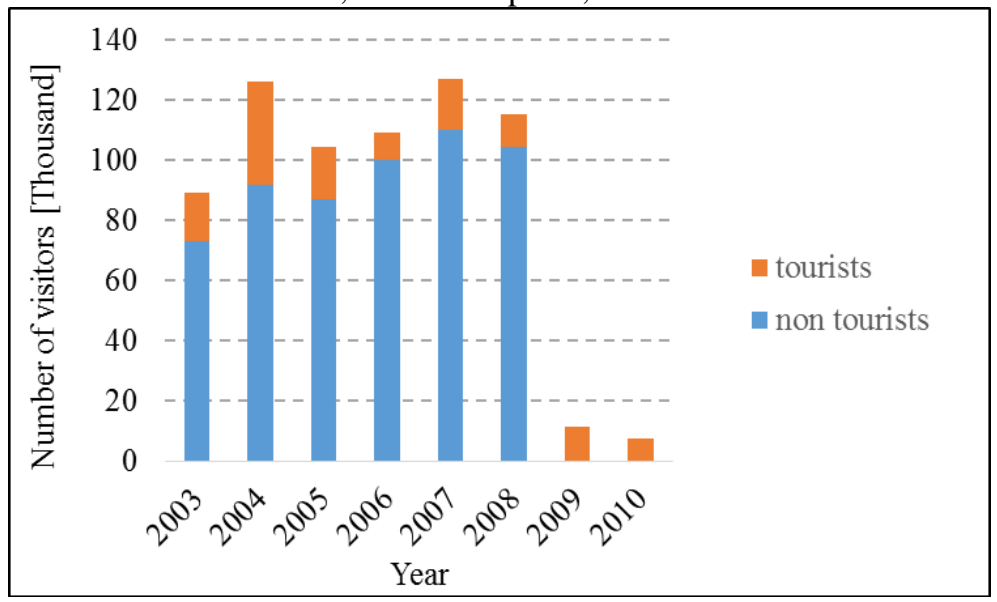

Fig. 0-1: Number of Visitors of Iran (in Thousand).

The questionnaire is divided into three sections; The first section of the questionnaire includes 8 factors related to the respondent's background, and it includes close ended questions. The second section of the questionnaire includes 6 questions related to the characteristics of Desert Tourism, which includes open questions. The third part of the questionnaire concerns factors of barriers and challenges. In fact, this 77 sections are the main section and helps to find out all barriers and challenges to desert tourism in Shahdad. The qualitative thematic analysis method was used to analyze and interpret the collected data. According to Braun 
and Clarke (2006), "Thematic analysis is identifying, analyzing and reporting patterns (themes) within data. It minimally organizes and describes your data set in detail. However, frequently it goes further than this, and interprets various aspects of the research topic".

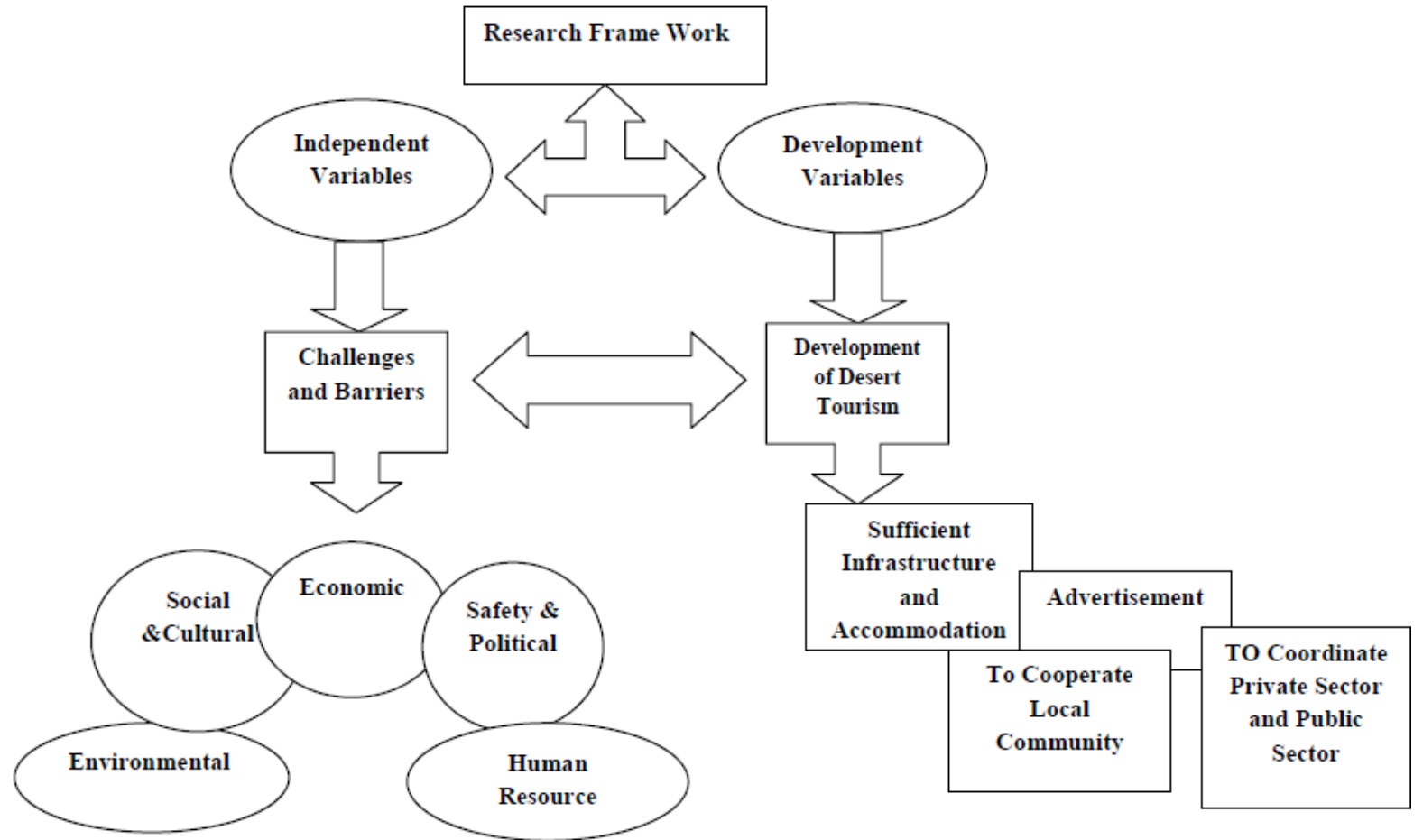

Fig. 0-2: Research Flowchart.

\section{Analysis of Results:}

According to the responses of agents, the mostly international tourist arrivals in this survey were from Germany, France, Spain and Italy that the $(20.7 \%),(16.1 \%),(12.6 \%)$ and $(11.5 \%)$ respectively, as shown in

Fig. 0-1. In the same way the majority of domestic travelers inside Iran were mostly from Tehran and Shiraz that percentages are $34.5 \%$ and $29.9 \%$ of totally, as shown in

Fig. 0-2.

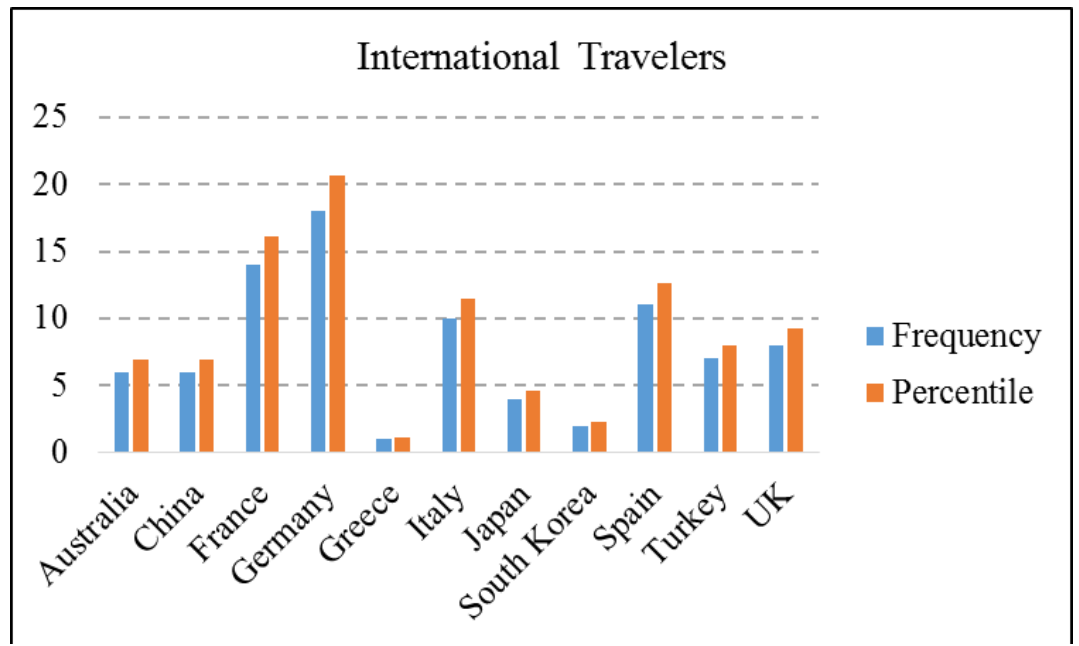

Fig. 0-1: Number of International Travelers in some developed countries. 


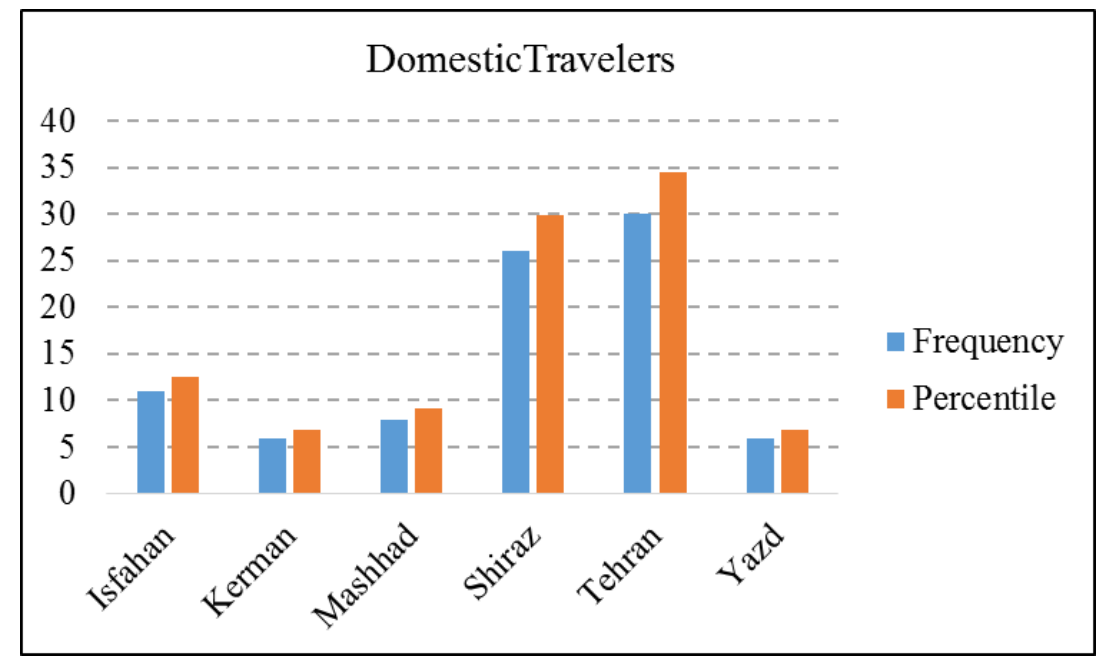

Fig. 0-2: Number of Domestic Travelers in some developed countries.

The respondent profile is presented in

Table $0-1$. Most of the respondents were male (57\%) and hold bachelor degrees $(55.2 \%)$. The results also show that $66 \%$ of the respondents have 11 to 20 years of working experiences. Most of the international tourists came from Germany (20\%) followed by France (16\%) and Spain (12\%). Tehran and Shiraz have the largest number of domestic tourists for visiting Shahdad desert. $77 \%$ of the agents had 1 to 10 tours to the Shahdad desert every year. Furthermore, most of the respondents claimed that the average cost of each tour is less than $\$ 51-100$. The findings indicated that from a total of 87 respondents, 50 were males accounting to the $57.5 \%$ of the sample. The balancing 37 respondents were females, representing the $42.5 \%$ of the respondents.

Table 0-1: Gender of Respondents

\begin{tabular}{|c|c|c|}
\hline Gender & Frequency & $\%$ \\
\hline Male & 50 & 57.5 \\
\hline Female & 37 & 42.5 \\
\hline
\end{tabular}

Table 0-2: Age of Respondents

\begin{tabular}{|c|c|c|}
\hline Age & Frequency & $\%$ \\
\hline $18-24$ & 8 & 9.2 \\
\hline $25-34$ & 34 & 39.1 \\
\hline $35-44$ & 39 & 44.8 \\
\hline $45-55$ & 6 & 6.9 \\
\hline
\end{tabular}

Among 87 respondents, the $18.4 \%$ reported a monthly income inferior than 100 USD, followed by a 72.4 in the 101-200 USD income, a $9.2 \%$ in the 201-300 USD income, while $0 \%$ of the respondents indicated that they earned between 301-400,401-500 and above 500 USD. Table 0-3: Age of Respondents

\begin{tabular}{|c|c|c|}
\hline Income & Frequency & $\%$ \\
\hline $101-200$ & 16 & 18.4 \\
\hline $201-300$ & 63 & 72.4 \\
\hline$>300$ & 8 & 9.2 \\
\hline
\end{tabular}

According to the responses of agents, the mostly international tourist arrivals in this survey were from Germany, France, Spain and Italy that the (20.7\%), (16.1\%), (12.6\%) and (11.5\%) respectively. According to responses of agents, the majority of domestic tourist were from Tehran and Shiraz that percentages are 34.5\% and $29.9 \%$. The two variables namely "Foreign tourists have the same freedom compare to other countries" and "There are proper vehicles to transport tourists" have the highest means of (4.49) and (4.41) respectively among the social and cultural barriers the positive items.. However most of the respondents disagreed with them. And the negative items "There are more restrictions for tourists In Islamic countries", "There are negative advertisements about this area which can affect on tourist attraction", "Lack of accommodation for tourist in desert" and "Lack of participation's local people" have the highest means of (4.26), (4.21) and (4.19) respectively. However, most of the respondents agreed with them. This suggests that these factors can be regarded as the most important barriers (see Table 0-4). The two items "There is enough supports from tourism organization to develop tourist industry in desert" and "Holding desert tours is expensive" have the highest 
mean (4.13 and 3.90) respectively. Moreover, the statistics show that the first item is positive and most of the respondents disagreed with it while the other one is negative, and most of the respondents agreed with it. This shows that these are the important factors of economic barriers.

From the economic view, there are a lot of problems between governmental sector and private sector. Based on the results obtained in the economic barriers section, most of the agencies as the private sectors believe that the governmental sector does not support them. The following reasons can be the causes of the lack of investment interest in tourism: Lack of certainty about the significant profit and efficiency, high interest of the loans and lack of cooperation from the banks, the high cost of electricity, water, telephone and the essential installations that are needed in tourism sites and hotels, the high cost of lands, the slow progress in getting the building license from the governor or other authorities, the problems of providing standard building materials in farfetched places and generally the lack of support from the formal organization that can be useful in emergency times.

Table 0-4: Social and Cultural Barriers.

\begin{tabular}{|c|c|c|}
\hline Statement & Mean & Std. Deviation \\
\hline There are more restrictions for tourists In Islamic countries & 4.2644 & 0.75421 \\
\hline $\begin{array}{c}\text { Foreign tourists have the same freedom compare to other } \\
\text { countries. }\end{array}$ & 4.4943 & 0.50287 \\
\hline $\begin{array}{c}\text { The tour guides should spend necessary trainings. } \\
\text { effect on tourist attraction }\end{array}$ & 2.4368 & 1.04215 \\
\hline Lack of participation's local people & 4.2184 & 0.55876 \\
\hline There are proper vehicles to transport tourists & 4.1954 & 0.80462 \\
\hline Lack of accommodation for tourist in desert & 4.4138 & 0.56139 \\
\hline There is a routine schedule for desert festivals & 4.2184 & 0.61805 \\
\hline The responsible about desert tourists is difficult & 3.0230 & 0.82090 \\
\hline
\end{tabular}

Table 0-5: Economic Barriers

\begin{tabular}{|c|c|c|}
\hline Statement & Mean & Std. Deviation \\
\hline $\begin{array}{c}\text { There is enough supports from tourism organization to develop } \\
\text { tourist industry in desert }\end{array}$ & 4.1379 & 0.76512 \\
\hline Foreign companies can invest in this industry & 2.7126 & 1.16047 \\
\hline No budget has funded before for advertising in this area & 3.4023 & 0.95795 \\
\hline Holding desert tours is expensive & 3.9080 & 0.72549 \\
\hline The local people can benefit from income of tourism & 2.4943 & 0.88756 \\
\hline
\end{tabular}

Thus, due to the mentioned reasons, the private sectors are not interested in investing in tourism. Regarding this the financial deputy and Travel Agents Monitoring mentioned different reasons for barriers: "Government has agreed to supports the private sectors for investing on desert tourism. But unfortunately, there have not been any proposals from private sectors since they haven't visited that region carefully and then make the decision about it, they want the government to prepare all the basis for them". "Private sectors don't invest on desert tourism, because they do not have enough information about desert tourism and don't trust its financial benefits". According to Regional Tourism Development strategies Project (2000) in Iran, it was mentioned about improving coordination and communication between the private and public sector facility and service providers. Some other barriers such as Political and Safety and Human resources are presented in full detail in (Annis Nobahar, the development of desert tourism in Shahdad Iran: barriers and challenges, master thesis, 2012).

\section{Conclusion:}

Since Iran Autonomous Region is one of the most immense region with wide-ranging desert. However, the desert development utilization and advertisement lagged behind Kerman province and the great value in the desert itself is not yet incarnated completely. This paper made an attempt to analyze systematically the characteristics and advantages of desert-tourism in Iran, Kerman. The author proposes some developmental tactics, which are the combination of exploitation and harness and protective development based on the study of orientating. Data was collected by distributing 120 questionnaires to the travel agencies as respondent who were specialized in Shahdad Desert. Seven people were selected from authorities of Cultural Heritage, Handicraft \& Tourism Organization in Kerman Province. The data was analyzed the statistical software package SPSS 16.0 for windows and thematic analysis. It is found that some improving of coordination and communication between the private and public sector facility and service providers. The other barriers such as Political and Safety and Human resources are found in this research.

Hence in the present study tried to identify the barriers of planning and development of desert tourism and the challenges of promoting desert tourism in Shahdad desert in Iran. It can be affirmatively concluded that all the research objectives and research questions have been successfully achieved. This study was an attempt to discover the current barriers and challenges in the development of tourism in Shadad desert regarding the 
viewpoints and ideas of private and governmental sectors. Based on the discussed barriers of desert tourist in Iran in this chapter and also the current barriers and challenges which have been mentioned in literature review, there are some strategies. It is hoped that desert tourism can be developed and improved through these strategies. But this cannot be fulfilled unless the authorities of tourism in Iran take this issue into consideration with more responsibility and sympathy.

\section{REFERENCES}

Annis Nobahar, 2012. The development of desert tourism in Shahdad Iran: barriers and challenges, master thesis.

Braun, V., and V. Clarke, 2006Using thematic analysis in psychology. Qualitative Research in Psychology, Iyvaskylan Yliopisto, 3: 77-101.

Capote, T., 1981. Tangier notes. In M. O’Brien (ed.) Travel in Vogue, pp: 110-12. London: Book Club Associates.

Creswell, W.J., 1994. Research Design Qualitative and Quantitative Approaches. Thousand Oaks, CA: Sage Publications, Inc.

Esfahani, M., and A. Padash, 2008. Investigating ways of public participation in

Ghosh, R.N., M.A.B. Siddique and R. Gabbay, 2003. Tourism and Economic Development : case studies from the Indian Ocean region. Business School The University of western Australia: Ashgate.

Hair, J.F., B. Black, B. Babin and R.E. Anderson, Eds., 2010. Multiple Variate Data Analysis (7th ed.): Pearson Prentice Hall.

Hickman, L., 2007. The Final Call: In Search of the True Costs of our Holidays (London: Eden Project Books).

Jick, T.D., 1979. Mixing qualitative and quantitative methods: Triangulation in action. Administrative Science Quarterly, 24: 602-611.

Kumar, C.R., 2008. Research methodology. New Delhi: S.B. Nangia.

McGrath, Cam., 2002. Dahab is losing its luster. Middle East Times. Retrieved from: www.mentimes.com/2k2/issues

Tourism Development, Journal of Cultural Management Research, before, third pre-issue, Tehran, Iran. 